\title{
Molecular Phylogeny of Ophiognominialeptostyla Isolates Collected from Iran Based on ITS nrDNA Sequences
}

\author{
Soleiman Jamshidi and Rasoul Zare
}

\begin{abstract}
Anthracnose is the most important fungal disease on Persian walnut in Iran. The current study was performed on 16 Ophiognomonialeptostyla isolates collected from northwest region of Iran. ITS amplification was performed by using ITS1 and ITS4 primers and the sequences were analyzed. Phylogenetic trees are made based on ITS sequences which showed that all Iranian isolates are in the same branch in a clade with Ophiognomonialeptostyla from CBS isolated from Juglansregia. The Iranian isolates are divided into two closely related sub-clades with low bootstrap support, the smaller sub-clade comprised of only three isolates were collected from wild walnut trees located in woodland areas.
\end{abstract}

Index Terms-Gnomonialeptostyla, ITS sequencing, phylogentic tree, walnut leaf blotch.

\section{INTRODUCTION}

Iran takes the third position in walnut production in the world (FAO, 2009). Persian or European walnut (Juglansregia L.) is common in most parts of Iran except the Persian Gulf coasts [1]. Walnut anthracnose or black spot/blotch is one of the most important fungal diseases on black walnut (Juglansnigra L.) in the North and South America and on Persian walnut in Europe and Asia [2]. It is widespread in Iran and has been reported from the north, west, northwest and northeast of the country [3]. Disease epidemics might be very destructive in rainy and cool seasons [2]-[4]. The causal agent is Ophiognomonialeptostyla (Fr.) Sogonov 2008, with Marssoniellajuglandis (Lib.) Höhn 1916 as its anamorph [5].

Genetic diversity of $O$. leptostyla has been poorly studied. Belisarioet al. (1992) surveyed on genetic variation of 176 Italian $O$. leptostyla isolates using PCR-RFLPs of ITS and $18 \mathrm{~S}$ rDNA and found no polymorphism [6]. Salahiet al. (2007) used the same technique with 30 Iranian isolates collected from East Azarbaijan province and the results were the same with no polymorphism [4]. Mejia et al. (2002) and Green \&Castlebury (2007) amplified ITS1 and ITS2 regions of nuclear ribosomal DNA in their studies about Gnomoniaceae phylogeny [5], [7]. Sogonovet al. (2008) studied four genes sequencing (tef 1, 28S rDNA, $\beta$-tubulin and RNA Polymerase II) in this genus and offered a new concept of Gnomonia and Ophiognomonia, and subsequently introduced the new combination which is currently used [8], [9]. ITS sequencing is one of the main tools in phylogenetic

Manuscript received July 15, 2010; revised October 20, 2012.

Soleiman Jamshidi is with the Department of Plant Protection, Islamic Azad University, Miyaneh Branch, Miyaneh, Iran (e-mail: s.jamshdi@m-iau.ac.ir).

Rasoul Zare is with the Department of Botany Iranian Research Institute of Plant Protection, Tehran, Iran (e-mail: simplicillium@yahoo.com). studies. In previous researches, ITS and LSU nrDNA RFLP-PCR was not useful for finding genetic diversity in Italian and Iranian isolates. The restriction enzymes which have been used might not cut the informative sites in ITS sequences. Therefore, in order to evaluate the ITS region sequences in evolutionary studies of this species among Iranian isolates, we sequences the ITS region of 16 isolates and compared them with those available at GenBank. Another aim of the study was to find genetic diversity among Iranian isolates.

\section{MATERIAL AND METHODS}

\section{A. Fungus Isolation and Mycelial Mass Production}

Sixteen Persian walnut leaf samples having anthracnose infection were collected from the northwest of Iran (Table 1) in spring and summer of 2006-08 and the causal agent were identified as $O$. leptostyla according to Sogonovet al. (2008). Three leaf discs (each $6 \mathrm{~mm}$-diameter) containing acervuli were surface sterilized using ethanol $75 \%$ (30 sec) and sodium hypochlorite $1 \%(60 \mathrm{sec})$, then were washed four times with sterile distilled water. Macroconidia were released by crushing leaf samples and picked off small leaf pieces in $1.5 \mathrm{ml}$ Eppendorph tubes containing $1 \mathrm{ml}$ sterile distilled water and vortexed for 20 seconds. Then, $100 \mathrm{ml}$ of conidial suspension were transferred into $2 \% \mathrm{WA}$ (water agar, Merck, Germany) and incubated at $21^{\circ} \mathrm{C}, 50 \% \mathrm{RH}$, dark condition. Germinating macroconidia were transferred to $39 \%$ PDA (potato dextrose agar, Merck, Germany) $+7 \mathrm{gr} / \mathrm{L}$ oatmeal and incubated at $21^{\circ} \mathrm{C}, 50 \% \mathrm{RH}$ and $12 / 12$ alternative photoperiod for 10 days. Obtained 10-day old mycelia were used for DNA extraction.

\section{B. DNA Extraction and Amplification}

DNA extraction was carried out according toslightly modified Liu et al. (2000). The ITS region (ITS1-5.8S-ITS2) was amplified using primers ITS1 [5'-tcc gtaggtgaacetgcg g] and ITS4 [5'-tcc tccgct tat tga tat gc] (White et al., 1990). The PCR reaction $(25 \mu \mathrm{l})$ contained $50 \mathrm{ng}$ of genomic DNA, 12.5 pmol of each primer, 0.3 mMdNTPs (CinnaGen, Tehran) and $1 \times$ PCR buffer containing $2 \mathrm{mM} \mathrm{MgCl}_{2}, 1.5 \mathrm{U}$ Taq DNA polymerase (Cinna Gen, Tehran). PCR amplification was carried out usingApollo (ATC. 401, ver. 4/88, CLP, Inc. USA) PCR machine. The PCR program for ITS region amplification was $94^{\circ} \mathrm{C} / 5 \mathrm{~min}$ (initial denaturation), $94^{\circ} \mathrm{C} / 40$ $\mathrm{s}, 50^{\circ} \mathrm{C} / 50 \mathrm{~s}, 72^{\circ} \mathrm{C} / 2 \mathrm{~min}(35 \times)$ and $72^{\circ} \mathrm{C} / 7 \mathrm{~min}$ (final extension). The PCR products were purified using a Genomic DNA Purification Kit, K0514, Fermentas). The purified DNA samples were then submitted to a capillary sequencing machine (Eurofins MWG Operon, Ebersburg, Germany). 
TABLE I: STUDIED ISOLATES.

\begin{tabular}{|c|c|c|c|}
\hline \multirow{2}{*}{ Acronym } & \multicolumn{3}{|c|}{ Sampling Information } \\
\hline & Location (Province) & Climate & Altitude \\
\hline Abs & Abhar - Shanat (Zanjan) & semi-arid cold & $1645^{\mathrm{b}}$ \\
\hline Aro & $\begin{array}{l}\text { Ardebil - Oskanlou } \\
\text { (Ardebil) }\end{array}$ & semi-humid cold & 1432 \\
\hline Asa & $\begin{array}{l}\text { Abhar - Sharif Abad } \\
\text { (Zanjan) }\end{array}$ & semi-arid cold & 1713 \\
\hline Fmn & Fuman (Gilan) & humid moderate & 50 \\
\hline Ggn & $\begin{array}{l}\text { Goovgan - Taimorlou } \\
\left(\mathrm{EA}^{\mathrm{a}}\right)\end{array}$ & arid cold & 1961 \\
\hline Glv & Gilvan (Gilan) & humid moderate & 493 \\
\hline Ile & Ilam - Eivan (Ilam) & semi-arid moderate & 1645 \\
\hline Mib & Miynah - Balesin (E.A) & arid cold & 1237 \\
\hline Mij & Miyaneh - Balojeh (EA) & arid cold & 1503 \\
\hline Mir & Taleghan - Mir (Tehran) & humid moderate & 1752 \\
\hline Mlk & Malekan (EA) & arid cold & 1294 \\
\hline Mrg & Maragheh (EA) & semi-arid cold & 1449 \\
\hline Mrs & Marivan - Seyf (Kurdestan) & semi-humid cold & 1563 \\
\hline Msl & Masouleh (Gilan) & humid cold & 1050 \\
\hline Qza & Qazvin - Abyek (Qazvin) & semi-arid cold & 1366 \\
\hline Shn & Taleghan -Sohan (Tehran) & humid moderate & 1895 \\
\hline
\end{tabular}

a. East Azarbaijan; b. in meter

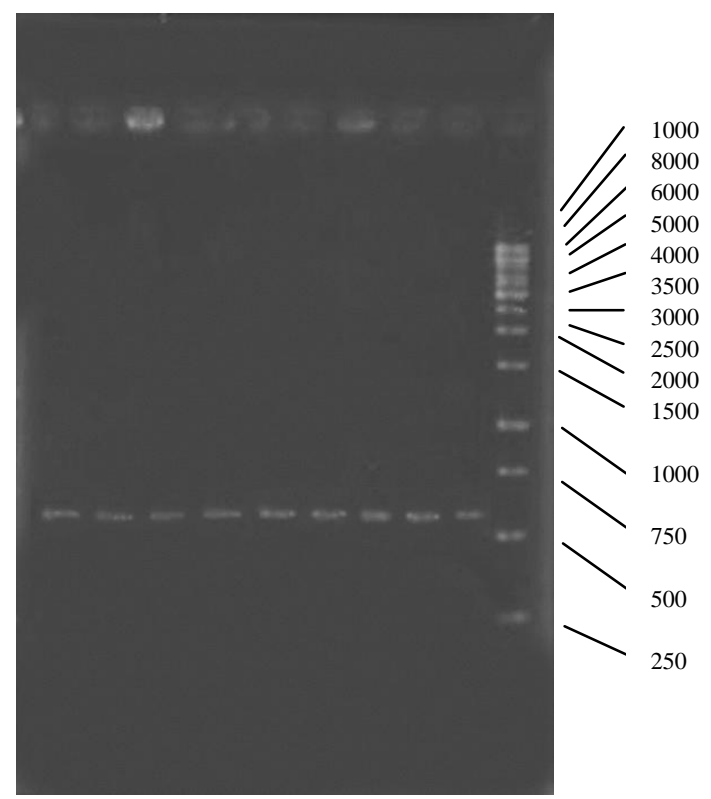

Fig. 1. Electrophoresis of ITS-PCR products on $1 \%$ agarose gel.

\section{Figuresphylogenetic Analysis}

The programs EditSeq and SeqMan, parts of the DNA*Lasergene (DNAstar, Madison, WI, USA) software package, were used to assemble and edit the sequence files. The alignments were initially obtained using the Pairwise Alignment option in GeneDoc (Nicholas and Nicholas, 1997). Sequences of the ITS region were analyzed using MEGA4 (Tamura et al., 2007). The phylogeny was inferred using the Distance (NJ) and Maximum Parsimony (MP) methods. The evolutionary distances were computed using the Maximum Composite Likelihood method (Tamura et al., 2004). All positions containing alignment gaps, and missing data were eliminated only in pairwise sequence comparisons (Pairwise deletion option). Relevant sequences fromGenbank were included in the analyses.

\section{RESULTS AND DISCUSSION}

The ITS region has been amplified and a single band (about 500 bp) was obtained as measured byagarose gel (Fig. 1). Similar ITS sequences were searched in BLASTGenbankand Gnomoniarostellatastrain CBS 856.79 isolated from strawberry was found the closest submitted ITS sequence to $O$. leptostyla, thus it was chosen as out-group.

\section{UNITS}

Phylogenetic trees reconstructed based on ITS sequences using parsimony and neighbor-joining methods showed that 13 Iranian isolates are in the same clade with Ophiognomonialeptostyla from CBS strains isolated from Juglansregia(CBS 110136, CBS 844.79 and CBS 110136). There were two closely related sub-clades with low bootstrap support on Iranian's. These two groups were very similar with only one informative site in ITS sequences. The results of parsimony agreed with those of neighbor-joining (Fig. 2 and Fig. 3).

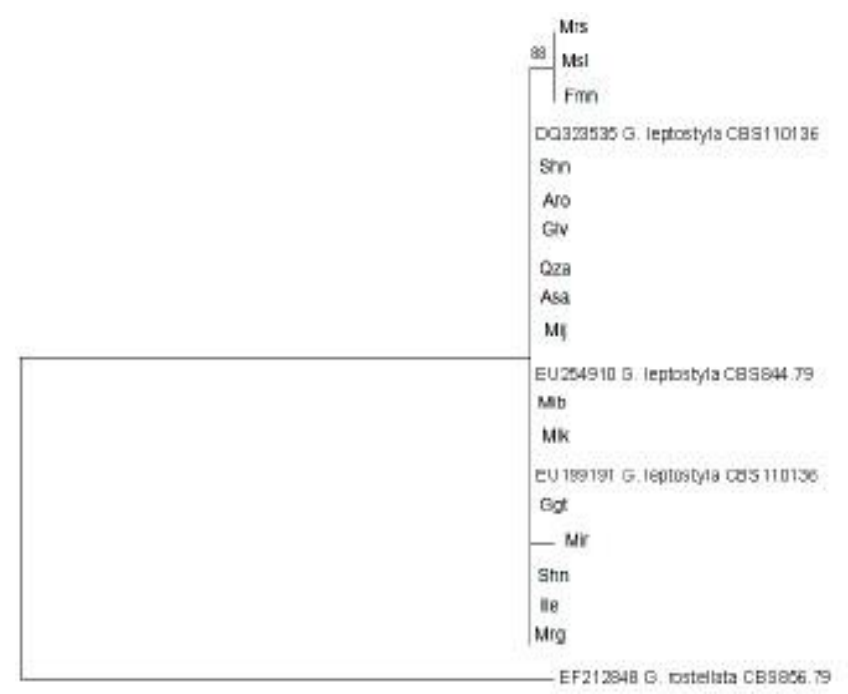

Fig. 2. Phylogenetic tree based on ITS sequences of Iranian and other isolates of Ophiognomonialeptostyla using NJ method.

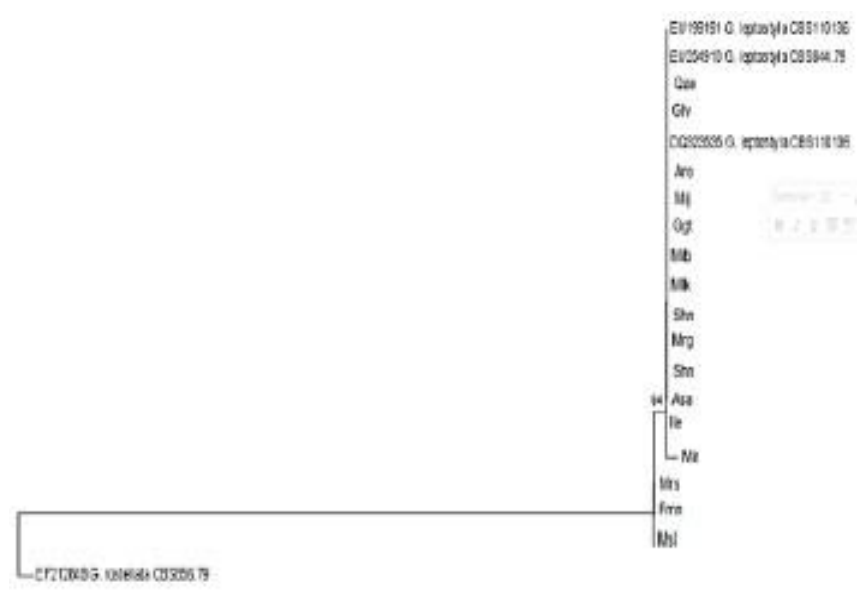

Fig. 3. Phylogenetic tree based on ITS sequences of Iranian and other isolates of Ophiognomonia leptostyla using parsimony method. 
Three isolates located on the same sub-clade were isolated from wild walnut trees in woodland area, considering the passible different variety of the species on these plants. It will be useful to use other gene sequences, such as tef and $\beta$-tubulin,to investigate the relationship of the three isolates from wild walnuts.

\section{ACKNOWLEDGMENT}

Special thanks to Dr. H. R. Zamanizadeh and Dr. S. Rezaee for their kind support. We are also grateful to Mr. M. Mokhtari and Mr. M. Mianaji for their assistance in Biotechnology Laboratory of IAU, Miyaneh Branch regarding this work.

\section{REFERENCES}

[1] M. Radnia and A. Ahmadi, Walnut, Tehran: Jihad Daneshghahi Publisher, 1997.

[2] A. Belisario, "Anthracnose," in Compendium of Nut Crop Diseases in Temperate Zones, B. L. Teviotdale, T. J. Michailides, and J. W. Pscheidt, Eds. USA: APS Press, pp. 77-78, 2002.

[3] E. Behdad, Plant protection encyclopedia of iran: Pests, diseases and weeds, Isfahan: Yad-Boud Publisher, 1991.

[4] S. Salahi, M. JavanNikkhah, and S. Jamshidi, "Study on population structure of Gnomonia leptostyla, causal agent of walnut anthracnose in East Azarbaijan province, Iran," New Agricultural Science Journal, vol. 3, no. 6, pp. 53-68, 2009.

[5] S. Green and L. A. Castlebury, "Connection of Gnomoniaintermedia to Disculabetulina and its relationship to other taxa in Gnomoniaceae," Mycological Research, vol. 111, pp. 62-69, 2007.
[6] A. Belisario, M. Scotton, A. Santori, and S. Onfri, "Variability in the Italian population of Gnomonialeptostyla, homothallism and resistance of Juglans species to anthracnose," Forest Pathology, vol. 38, pp. 129-145, 2008.

[7] L. C. Mejia, L. A. Castlebury, A. Y. Rossman, M. V. Sogonov, and J. F. White, "Phylogenetic placement and taxonomic review of the genus Cryptosporella and its synonyms Ophiovalsa and Winterella (Gnomoniaceae, Diaporthales)," Mycolgical Research, vol. 112, no. 1, pp. 23-35, 2008.

[8] M. V. Sogonov, L. A. Castlebury, A. Y. Rossman, L. C. Mejia, and J. F. White, "Leaf-inhabiting genera of the Gnomoniaceae,Diaporthales," Studies in Mycology, vol. 62, pp. 1-79, 2008.

[9] L. A. Castlebury, A. Y. Rossman, W. J. Jaklitsch, and L. Vasilyeva, “A preliminary overview of the Diaporthales based on large subunit nuclear ribosomal DNA sequences," Mycologia, vol. 94, no. 6, pp. 1017-1031, 2002.

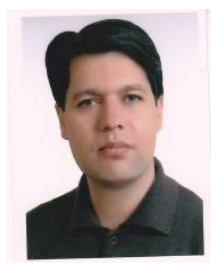

Soleiman Jamshidi was born in Miyaneh, Iran in 21 March, 1974. He received his B.Sc. degree in plant protection from Tabriz University in Tabriz, Iran M.Sc. degree in plant pathology from Ferdowsi University of Mashhad, Mashhad, Iran, and Ph.D. degree in plantpathology and fungal diseases from Islamic Azad University, Science and Research Branch of Tehran. He started working as academic staff since 2001 in Islamic Azad University, Miyaneh Branch and was Vice-President in Research Affairs in this university for 4 years starting 2003 until 2007. He is now Vice-President in Education and Student Affairs of Agriculture and Natural Science Faculty in the same university. His research interest is fungal phylogeny ad plant disease management. Dr. Jamshidi is member of Iranian Plant Pathologist and Iranian Mycologist Society member. 